\title{
Rapid Change Without Transformation: the Dominance of a National Policy Paradigm over International Influences on ECEC Development in Ireland 1995-2012
}

\author{
Noirin Hayes \\ Technological University Dublin, noirin.hayes@tudublin.ie \\ Bernie O'Donoghue Hynes \\ Technological University Dubin, bernie.odonoghue@tudublin.ie \\ Toby Wolfe \\ Start Strong
}

Follow this and additional works at: https://arrow.tudublin.ie/cserart

Part of the Other Education Commons, Political Science Commons, Public Policy Commons, and the Social Policy Commons

\section{Recommended Citation}

Hayes, N., O'Donoghue-Hynes, B., Wolfe, T. (2013) Rapid Change without Transformation: The Dominance of a National Policy Paradigm over International Influences on ECEC Development in Ireland 1995-2012. International Journal of Early Childhood, vol. 45, no. 2, August, special issue "National Policies in a Globalised World", pp.191-205. doi:10.1007/s13158-013-0090-5

This Article is brought to you for free and open access by the Centre for Social and Educational Research at ARROW@TU Dublin. It has been accepted for inclusion in Articles by an authorized administrator of ARROW@TU Dublin. For more information, please contact arrow.admin@tudublin.ie, aisling.coyne@tudublin.ie, gerard.connolly@tudublin.ie.

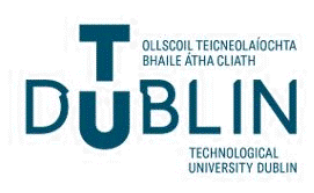




\section{Rapid Change without Transformation: The Dominance of a National Policy Paradigm}

over International Influences on ECEC Development in Ireland 1995-2012

by

Toby Wolfe (Start Strong)

Bernie O’Donoghue-Hynes (Dublin Institute of Technology)

Nóirín Hayes (Centre for Social and Educational Research, Dublin Institute of Technology)

Published in:

International Journal of Early Childhood, Volume 45, Issue 2, August 2013, special issue "National Policies in a Globalised World", pp.191-205.

The final publication is available at link.springer.com:

http://link.springer.com/article/10.1007/s13158-013-0090-5

Address for correspondence:

Toby Wolfe, Start Strong, toby.wolfe@ startstrong.ie 


\title{
Rapid Change without Transformation: The Dominance of a National Policy Paradigm over International Influences on ECEC Development in Ireland 1995-2012
}

\begin{abstract}
The rapidity of change in Irish early childhood policy over the last 20 years is clear to observers (OECD 2004). What may be debated is how significant the changes are. In this paper, we analyse changes in early childhood education and care policy in Ireland since 1995, using Hall's (1993) typology of policy change to help understand how policies and institutions could change so much in appearance without changing their fundamental features or underlying philosophy. We demonstrate that, despite extensive change, a traditional policy paradigm has held constant, where the State's role in direct service delivery remains limited, the State continues to be reluctant to intervene in "family matters" and education is prioritised over care.
\end{abstract}

\section{Résumé}

Il est evident aux yeux des observateurs que la politique irlandaise de l'éducation et l'accueil de la petite enfance a rapidement changé au cours des vingt dernières années (OCDE, 2004). Reste à savoir à quel point ces changements sont significatifs. Dans cet article, nous analysons l'évolution de la politique d'éducation et d'accueil de la petite enfance en Irlande depuis 1995, au moyen de la typologie du changement de politique de Hall (1993) pour aider à comprendre comment les politiques et les institutions peuvent tant changer en apparence sans que changent leurs caractéristiques fondamentales ni leurs philosophie sous-jacente. Nous démontrons qu'en dépit de changements importants, un paradigme de politique traditionnelle est resté constant, alors que le rôle de l'Etat demeure limité dans les services offerts. L'Etat reste réticent à intervenir dans "les affaires familiales" et la priorité est donnée à l'éducation plutôt qu'à l'accueil.

\section{Resumen}

En los últimos veinte años Irlanda ha experimentado una rápida transformación en la política sobre el cuidado y educación infantil; esto es algo evidente para los observadores del tema (OECD 2004). Lo que podría debatirse es la importancia de estos cambios. En este ensayo analizamos los cambios en el sistema educativo infantil y en la política de cuidado infantil en Irlanda desde 1995, utilizando la clasificación de Hall (1993) para evaluar el grado de cambio en la política para ayudar a entender cómo las políticas y las instituciones pueden haber 
cambiado tanto en apariencia, pero sin haber experimentado grandes cambios ni en sus características fundamentales ni en su filosofía de base. Este ensayo demuestra que, a pesar del gran cambio experimentado, un paradigma de política tradicional, en el que el papel del Estado en la provisión de servicios continúa siendo limitado, se ha mantenido constante; el Estado continúa estando poco dispuesto a inmiscuirse en "asuntos familiares", y que a la educación se le da mayor importancia que al cuidado infantil.

\section{Introduction}

In 1995, Hayes wrote "there is no national policy or philosophy generally about early childhood services" in Ireland, arguing that early years services had developed in an ad hoc manner reflecting the Irish State's minimal engagement with childcare, while early education took place within primary schools, open to children aged 4 and over. Services were unregulated and there was minimum coordination at policy level, with over eight departments having some level of responsibility (Hayes 1995).

However, from the late 1990s a series of policy reforms and large-scale public investment in early years services in Ireland was evident. Growing exposure to international influences saw a shift in the language of policy debate from childcare as a welfare support for working mothers to early childhood care and education as a social investment in children. Finally, in response to the previous lack of an explicit national policy, the Minister for Children and Youth Affairs announced the development of Ireland's first National Early Years Strategy in January 2012.

It is a story that could be presented as one of rapid policy formation driven by global developments, especially EU funding instruments, the OECD's Starting Strong process, and international cost-benefit analysis of early childhood programmes. Indeed, the occasion and justification of the Minister's announcement in January 2012 could itself be seen as symbolic of the changed policy context. The announcement, made at an inter-governmental seminar during the launch of the OECD's Starting Strong III (2012) report, referred to "increasing acceptance and focus internationally on the economic benefits accruing from investment in the early years. Longitudinal studies in the US, England, France and New Zealand cite returns to the economy of between three and ten times the original investment" (Department of Children and Youth Affairs, 2012).

Despite the appearance of change, we argue in this paper that the fundamental features of Irish Early Childhood Education and Care [ECEC] policy remain. Using Hall's (1993) typology of policy change as a framework for analysis, we argue that the settings and 
instruments of policy have changed significantly since 1995, but within an unchanging policy paradigm. The theme of the paper is the resistance of domestic policy to external influences, whether national or international, and we characterise the period as one of rapid policy change without transformation.

We first introduce Hall's typology, before outlining the paradigm. An analysis of policy developments between 1995 and 2012 follows before we draw the analysis together with reference to Hall's typology.

\section{Analytical Framework}

Hall's typology of policy change applies Kuhn's (1962) concept of paradigms in scientific thought to the field of public policy. Recognising that economic policy is a dynamic process, Hall uses the concept of a "policy paradigm" to distinguish economic policy changes that remain within the existing policy paradigm from the sort of radical change that moved UK economic policy from a Keynesian to a monetarist paradigm in the 1980s. Daly (2010) applied Hall's typology to the development of UK family policy since 1997, arguing that significant developments in UK family policy during this period did not amount to a paradigm change and, more recently the typology has been used to consider current reforms in the Swedish preschool system (Jonsson et al. 2012).

A central focus of Hall's typology is processes of social learning. While ideas which are at the core of a policy paradigm - can be embedded in institutions, Hall argues that they have a somewhat independent status and can provide the basis for the reform of institutions. For Hall, the flow of ideas is itself an aspect of politics and power relations. While some policy changes are routine, involving normal processes of social learning in public policy, some policy changes follow a rupture in these processes and signify a change in the locus of authority and source of ideas. Hall's focus on ideas and processes of social learning encourages us to look at the language of political discourse and the ideas it embodies, and also at the sources and types of influence that drive policy change - whether internal or external to the State.

Hall describes three orders of policy change, distinguishing changes in policy settings, policy instruments and the policy paradigm. The third order "policy paradigm" change involves: change in the goals of policy and the "framework of ideas", where the framework of ideas specifies not only the goals "but the very nature of the problems they are meant to be addressing" (p.279); a shift in "social learning", with policy learning driven to change through external influences rather than routine processes of social learning; and changes that 
are preceded by a period of experiment, anomalies or evident policy failures which "stretch the intellectual coherence of the policy paradigm that was supposed to be guiding policy to the point of breaking" (p.285).

The concept of policy paradigm has been applied to Irish education policy by O'Sullivan (2005), who examined the connections between Irish education policy, culture and social change since the $1950 \mathrm{~s}$, including the shift from what he termed a theocentric to a mercantile policy paradigm. While O'Sullivan looked broadly at education policy, we focus specifically on early childhood education and care.

\section{Ireland's Social Policy Paradigm}

Early childhood education and care is a relatively new policy area for the Irish State, but the funding and support mechanisms used have been informed by the State's past actions. This is in line with path dependency theory (Pierson 2000), which suggests that past actions inform the future trajectory of policy decisions. The policy paradigm embodies views of how family, the State and private service providers interact to address education, family policy and labour market goals. Three distinct features of the Irish social policy paradigm are evident: the State's limited role in direct service delivery; the State's reluctance to intervene in "family matters"; and the prioritisation of education over care.

Before examining these, we outline key aspects of ECEC provision in Ireland. Ireland has a "split system" of ECEC provision (Kaga et al. 2010). The compulsory school startingage is 6 , but half of 4 year olds and nearly all 5 year olds attend State-funded primary schools under the auspices of the Department of Education, where they are taught by graduate primary school teachers. ECEC policy prior to school entry has been the responsibility of a series of other Government Departments. ECEC provision comprises a mixture of private forprofit services, "community" non-profit services in disadvantaged areas, and home-based "childminders". Until recently there were no qualification requirements for staff working in any of these services, and regulations largely related to health and safety. ECEC services compete with each other in a free-market model, with little public coordination of provision. Public funding was largely limited to "community" services until the introduction in 2010 of a Free Pre-School Year which is available in both private and community services for all 3-4 year olds in the year before school entry, for 3 hours per day, during school terms. Provision for under-3s remains limited in extent and unsubsidised except for certain disadvantaged families accessing community services. ECEC costs to most parents remain among the highest in the EU. Overall, public funding of early childhood services in Ireland is low by 
international standards, with funding concentrated instead on cash payments for children and families (OECD 2009).

\section{The State's Limited Role in Service Delivery}

The Irish State has historically adopted a limited role in direct service delivery, with health and education institutions - including ECEC services - largely owned and operated by private and voluntary providers. Lloyd notes that the recent growth of the market model of childcare provision is common to both historically liberal welfare regimes, where it has been the dominant approach, and other welfare regimes that have gone through processes of liberalisation and the commissioning out of public provision to private providers (Lloyd 2012). In Ireland, across many areas of social policy, Irish scholars have observed a shift towards a form of neo-liberalism in which "[p]ublic goods, related to social justice and redistribution, are increasingly privatised, while their distribution becomes more consumer driven and less based on rights derived from citizenship" (Murphy 2006, p.2).

Adshead (2008), however, argues that the Irish State's reliance on funding and support mechanisms that facilitate dependence on third parties is due to the historic reliance on the Catholic Church to deliver public services such as health and education, rather than any ideological commitment. Both the main political parties have adopted centre-right policy positions, and there is no political tradition of reformist liberalism. The gap left by the withdrawal of the church from service delivery in recent years has been filled by private service providers and, in areas of disadvantage, the community and voluntary sector.

\section{Governmental Reluctance to Intervene in "Family Matters"}

In Ireland, a conservative view of family permeates family policy design, providing a rationale for non-involvement in the affairs of families (Hantrais 2004). This traditionalist view acts as an impediment to the adoption of a neo-liberal approach to female participation in the labour force.

The Irish Constitution asserts that "The state shall therefore endeavour to ensure that mothers shall not be obliged by economic necessity to engage in labour to the neglect of their duties in the home" (Bunreacht na hEireann 1937, Article 41.2.2). Politically there has been a reluctance to shift far from this constitutional position in which mothers are granted social protection from the labour market (Daly and Clavero 2002; Rush 2006). In fact, it is difficult to identify any significant shift in the State's position since the First Commission on the Status on Women (1972) reported that: 
... very young children, at least up to 3 years of age, should, if possible, be cared for by the mother at home and that as far as re-entry to employment is concerned, the provision of day-care for such children must be viewed as a solution to the problem of the mother who has particularly strong reasons to resume employment (paragraph 310)

The Irish State's preferred policy instrument for supporting families has been direct cash payments to parents that have not been conditional on labour market participation, avoiding the direct provision of ECEC services that might be seen as a restriction of parental choice in relation to care options (OECD 2010; O’Donoghue-Hynes 2012).

\section{Prioritisation of Education over Care}

Historically, the family was positioned as having primary responsibility for the care of family members and as being the primary natural educator of children (Bunreacht na hEireann 1937; Government of Ireland 2000). However, unlike the State's distanced position in relation to what is considered care, the Irish State assumed direct responsibility for early education through the provision of infant classes within primary schools for children from the age of 4 years old, two years before the compulsory school starting-age. The State has thus prioritised the education model over the work-care reconciliation model for pre-school provision (Scheiwe and Willekens 2009).

Government policies persist in drawing a distinction between childcare, as a welfare service, and early education, as an educational service, despite arguments encouraging a coordinated and integrated policy approach (OECD 2004; NESF 2005; Hayes 2006) and in spite of acknowledgement, even from Government, that the integration of early education and care is desirable. The Government's White Paper on early childhood education, Ready to Learn, (Department of Education and Science 1999) claimed that "one of [the White Paper's] key underlying principles is that, for young children, education and care should not be separated, but should be provided in a complementary, seamless fashion" (s.1.1), but immediately went on to argue that:

Care is the dominant requirement of children aged less than 3 years and, because education is a more significant need of older children, the principal, though not 
exclusive, policy focus of this White Paper is on children aged between 3 and 6 years (ibid).

Professional requirements in relation to primary school teacher qualifications are well established and cover the infant classes for 4-6 year olds within primary schools. The same requirements for professional standards have not applied to ECEC (O'Donoghue-Hynes 2012) as the regulations require only that staff be "suitable and competent adults" (Government of Ireland 2006, p.6).

In 1994 the State's responsibility for early education was extended, through the Department of Education, to a limited number of younger children (aged 3-4) in a targeted Early Start approach to tackle educational disadvantage within designated geographic areas and communities (Education Research Centre 1998). While slightly moving the boundary between childcare and early education, the Early Start programme continued to fit within the existing divide.

\section{A Period of Change - 1995-2012}

\section{From the EOCP to the NCIP}

A process of policy development had begun in the 1990s with the Pre-School Regulations of 1996 and two major initiatives to re-examine the early years policy framework: the white paper Ready to Learn (Department of Education and Science 1999), and the Partnership 2000 Expert Working Group report (Government of Ireland 1999). However, it was only with EU Structural Funds that significant public investment went into the sector.

Post 2000, the State accessed the EU European Regional Development Fund and invested in childcare under an equality brief that aimed to address barriers to parental participation in the workforce. Channeled through the Equal Opportunities Childcare Programme (EOCP) from 2000-2006, funds were made available primarily through capital grants for the construction of childcare facilities. Approximately 47,000 new childcare places were created, a significant achievement given that in 1999/2000 just 56,803 children were attending childcare facilities (ADM 2000). In addition, 33 City/County Childcare Committees (CCCs) were established at local level - the first time the Irish State had appointed local administrative structures with responsibility for childcare. 
As community services were located in areas of disadvantage where many parents could not afford to pay the market rate, the issue of sustainability was always a concern. In response a staffing grant was developed to pay for up to three full time staff in each participating service. However, this funding was insufficient and many community services relied on the State-supported Community Employment ${ }^{1}$ scheme to secure adequate numbers of staff. The persons participating tended to be untrained and worked part-time for a limited duration.

Subsequent to the EOCP, the National Childcare Investment Programme (NCIP) 2007-2010, a programme fully funded by the Irish Government, was introduced. The Government reconfigured the funding mechanisms, replacing the operational Staffing Grant with the Community Childcare Subvention Scheme (CCSS), which provided a fee subsidy to service providers based on the number of parents in receipt of welfare.

The investment programme changed the ECEC landscape but it retained the care/education divide. The policies embodied in the EOCP and NCIP were driven by the aims of social inclusion and the labour market participation of disadvantaged parents. EU funding acted as an international driver, supporting women's labour market participation and the growth of ECEC provision. However, this labour market goal was at odds with the existing Irish policy goal of neutrality in relation to mothers' decisions as to whether to stay at home or go out to work, a policy goal which was a key factor in driving a significant increase in universal cash payments at exactly the same time.

\section{Financial Supports for Families}

The main financial support for families is Child Benefit, an unconditional, monthly cash payment to the primary carer (normally the mother) of every child in the State. While a universal payment, there have been attempts to reconstruct Child Benefit as an antipoverty payment, opening up the doors to a discourse on taxing or means testing the payment, a debate currently active in the environment of austerity. The same payment has also been promoted as the primary mechanism of the State to supports parents meeting the cost of childcare. In his December 2000 Budget speech to the Dáil (House of Representatives), the Minister for Finance justified a large increase in Child Benefit by saying that:

\footnotetext{
1 The Community Employment Scheme is an Active Labour Market Programme where the long-term unemployed can participate in part-time and temporary community based job placements.
} 
The House will be well aware of the great diversity of views that are held in relation to addressing the childcare issue. The Government's core objective is to provide support which will offer real choice to parents and will benefit all our children. This we can do through Child Benefit. (Department of Finance, 2000).

The rate of Child Benefit increased threefold between 1999 and 2003. Politically the change responded to rising concern in the electorate about the affordability of childcare. In policy terms, the large increase in spending was a "response to several concerns, namely to reduce work disincentives for families reliant on social welfare, to support working parents with the cost of childcare and to recognise the value of work in caring for children in the home" (Sweeney 2007, p.88).

While the rate of increase slowed down in 2003, cash payments continued to be the political solution to addressing childcare concerns, despite growing external pressure for a new policy approach. The 2004 OECD Starting Strong evaluation was followed by other reports (NESF 2005, National Women's Council of Ireland 2005) all recommending the development of a national plan for early childhood services, an increase in investment, implementation of a quality framework, professionalisation, and the introduction of universal pre-school provision for 3 and 4 year olds.

These influences converged with the rapid emergence of childcare as a policy issue, articulated to politicians on the doorsteps, linked to the rise in women's labour market participation with the economic boom. In 2006 the Government announced a large increase in Government spending on early childhood through the introduction of an Early Childcare Supplement (ECS). This was an additional annual cash payment to parents of $€ 1000$ p.a. for children under the age of six, increasing the total cash payment (Child Benefit plus ECS) for every child under the age of 6 to $€ 2,800$ per annum in 2006 (Department of Social and Family Affairs 2006), more than five times the level in 1999.

It was the first dedicated, universal "childcare" cash payment, and it allowed the Government to avoid controversy in relation to favouring working parents over stay-at-home parents. This point was highlighted by the Minister for Children who said that, "[1]ike Child Benefit, the Early Childcare Supplement will support all parents irrespective of income or employment status" (OMCYA 2006). The Minister went on to outline the role of these cash payments in addressing the goals of both family and childcare policy, making no distinction between them: 
...[T]he Government is taking a serious and long-term approach to childcare based on the continued development of sound policies and substantial programmes of investment to ensure the future welfare of our children and to assist their parents in their daily lives. (ibid)

In line with policy instrument selection decisions for family policy, the Government opted for the costly, highly visible and politically attractive cash payment rather than funding service provision, ensuring the State did not intervene directly in family decisions. At the time, the State was famously "awash" with money (Clancy 2006) so the high visibility of a budget of close to $€ 500$ million p.a. was of little concern until 2008.

\section{The Free Pre-School Year}

When Ireland's economy moved into recession in 2008, the ECS immediately came under scrutiny. Possibly because of its novelty and also because of its inadequacy as an instrument to address the problem of high childcare costs for which it was introduced, the ECS did not command deep-rooted public support. Minor reductions made in the October 2008 Budget and the February 2009 Budget adjustments were met with little public opposition. In the April 2009 Supplementary Budget the ECS was abolished and replaced by a free pre-school year. As a key recommendation of actors within the sector over a number of years, the move received a largely positive welcome even though the new scheme's annual budget of $€ 170$ million was only $35 \%$ of the previous annual cost of the ECS, giving the State a large financial saving (Start Strong, 2009).

The new scheme's full name was the "Free Pre-School Year in Early Childhood Care and Education (ECCE) Programme", and it is regularly referred to in official documents as "the ECCE programme". The authors of this paper consider that this name misrepresents the narrow remit and purpose of the scheme and so they refer to it as the Free Pre-School Year (FPSY). The FPSY is typically provided 3 hours a day, 5 days a week, over 38 weeks, and children can start it between the age of 3 years 2 months and 4 years 7 months. The Government looked to the existing early years infrastructure to deliver the service, relying heavily on private service provision. Within one year of operation the initiative had participation rates in excess of $90 \%$ of all eligible children (Department of Children and Youth Affairs 2011).

The FPSY brought Irish ECEC policy more closely in line with international policy development. Justification for the scheme also saw a change in language, reflecting a 
growing tendency to refer to the findings of international research on child development, in particular the US cost-benefit analyses of early childhood programmes. When announced, the Minister for Finance argued that it "enhance[d] the subsequent educational achievement of students and in turn increase[d] the return for State investment in education generally" (Department of Finance, 2009).

In important respects the scheme could be seen to signal a marked change in ECEC policy in Ireland - the funding went to services not parents, free places were introduced for the first time, and there was a universal ECEC scheme outside the primary school system. The CCSS remained a social inclusion initiative to which minimal regulations applied, while in contrast a key condition of FPSY funding was that a member of staff must meet a minimum qualification requirement (with a financial incentive for services to employ a graduate), and settings were, in principle, required to take account of the national framework documents on quality, Síolta (Centre for Early Childhood Development \& Education 2006), and curriculum, Aistear (National Council for Curriculum and Assessment 2009).

However, the scheme also embodied a great deal of continuity in ECEC policy. It was characterised as a school-readiness initiative, thus maintaining the care/education divide, albeit with early education now beginning at the age of 3 years 2 months rather than 4 . In fact it may have exacerbated the divide through incentivising early childhood services to put their more qualified staff with the older age group of young children. It also retained the market model of provision. By making access to the scheme conditional on the local availability of places, with no mechanism for coordinating and ensuring the availability or quality of places, the scheme avoided the introduction of rights or entitlements into ECEC policy. Neither did the scheme reverse the policy of neutrality towards parents' decisions on whether to work or stay at home; the hours of the scheme were not designed to facilitate parental employment.

\section{The Minimal Implementation of Síolta and Aistear}

Alongside the investment and policy initiatives introduced above, the Government also funded two organisations - the Centre for Early Childhood Development and Education [CECDE] and the National Council for Curriculum and Assessment [NCCA] - to develop national quality and curriculum frameworks respectively. While funding the development of the two frameworks, Síolta and Aistear, the Government made no commitment to implement or support them. Their development involved inclusive processes with a wide range of actors from across the broad ECEC sector, from home-based care to infant classes in primary schools. Both frameworks drew heavily on international research, and their contents and 
design reflected contemporary views of ECEC and children. Síolta and Aistear are designed to support the whole 0-6 age-range, with a strong focus on the integration of care and education. They embody a conception of children's rights as the basis for ECEC practice, and they are at odds with the prevailing policy paradigm.

It is revealing, therefore, that their implementation has been slow and partial and has actually reflected the care/education divide that the two frameworks strive to overturn (Hayes 2006). Síolta was published in 2006 with no implementation plan; in practice it remains optional although adherence is expected within the FPSY for 3-4 year olds. Aistear was published in 2009 and it too remains effectively optional, only being actively promoted in the infant classes of primary schools.

The lack of policy focus on the quality of ECEC practice in services extended also to professional development. A Workforce Development Plan published in 2010 (Department of Education and Skills) had no resources allocated to implementation so its ambitions were limited. Possibly the most significant development in relation to professionalisation - the qualification requirement introduced with the FPSY - does not extend to any children under 3 years.

\section{Analysis of Policy Changes}

The policy changes described have resulted in significant changes to infrastructural, financial and policy frameworks for ECEC services in Ireland. The landscape of early childhood provision looks markedly different in 2013 to its appearance in 1995. In terms of change in settings - Hall's $1^{\text {st }}$ order policy change - access to EU funding made possible a large expansion in ECEC places and provided for a new local administrative infrastructure. In terms of change in instruments - Hall's $2^{\text {nd }}$ order change - a series of new policy instruments were developed, including capital grants, subsidy funding for community sector providers, and a universal, free pre-school year.

The FPSY has created a new policy lever that has the potential to bring about more far-reaching $3^{\text {rd }}$ order policy change in future. Until the FPSY, the Irish State had few policy levers to influence directly the quality of provision. The State now has direct funding contracts with over $90 \%$ of early childhood service providers, putting the Government in a position where it can impose conditions in those contracts, including conditions relating to quality.

Nevertheless, while there have been significant changes in settings and instruments, and while it can be hard to distinguish incremental modifications from radical (paradigm- 
shifting) changes in single-country studies (Scheiwe and Willekens, 2009), the policy paradigm remains. The State still has a very limited role in direct service delivery, relying instead on the private and community sectors, who now have high levels of dependence on State funding but remain independently governed.

Irish Governments have continued to be reluctant to intervene in 'family matters', as was evidenced through the rapid rise in Child Benefit and the replacement of the ECS by the FPSY. The latter could be seen as a more activist approach by the Government towards parents' ECEC decision-making. However, with the FPSY falling on the education side of the care/education divide, the scheme reflects an extension to 3 year olds of the long-accepted relationship of the State and family in relation to the education and enrolment of 4 and 5 year olds in primary schools. More broadly, the State has continued to prioritise education over care, especially in relation to qualification requirements and other quality measures.

Referring back to Hall's typology, we make the following observations:

The goals of policy have not changed.

While nominally the concern of the education system has shifted to a younger age, the fundamental split between early education for 3-6 year olds and childcare for 0-3 year olds, remains. The stated goals of the FPSY are educational; the goals of policies affecting 0-3 year olds continue to be a mix of social inclusion and neutrality in relation to families' ECEC decisions.

There has been no change in the framework of ideas.

There has been a shift in the language used by policy makers, from "childcare" to "ECCE", with the FPSY being presented as "an investment in education". However, the language changes have not been reflected in policy changes, with only limited steps to support the quality improvements that would align the FPSY to educational policy and no extension of an educational perspective to younger children. Children's rights continued to be absent from policy documents throughout this period, with the FPSY designed in such a way as to avoid establishing a right.

There has been no change in the locus of authority or disruption of the State's processes of social learning.

In spite of growing reference to international actors and documents in policy debate, there has been no shift in the locus of authority. EU funding allowed a transformation of the 
infrastructural landscape, but its influence was filtered through domestic policy-making structures. The OECD's Starting Strong process informed critiques of Irish policies, and may ultimately have contributed to the introduction of the FPSY, but did not alter the State's preference for the cash payment approach. While the design of the FPSY reflected similar schemes in other jurisdictions, it was embedded in existing structures. International influence was more apparent in the development of quality and curriculum frameworks, but no policies were developed to support, implement or evaluate these frameworks.

At a political level, there has been no disruption of social learning processes. The ECEC sector was actively engaged in the work of the 1999 Expert Working Group, which may have had a politicising effect but had limited impact on subsequent policy development. In the first half of the 2000s, the high cost of childcare to parents became a major policy issue but was effectively defused - though not resolved - by increases in Child Benefit and the introduction of the ECS. Within the ECEC sector, which does not have a long history of political mobilisation in Ireland, opposition to new policies arose in relation to both the ending of the Staffing Grants (Irish Childcare Policy Network 2008; PLANET 2008), and the introduction of the FPSY (National Association of Private Childcare Providers 2010), but in neither case did the opposition win policy concessions.

\section{Periods of experiment and anomaly?}

This aspect of Hall's typology is hard to assess except with hindsight, as there are often perceived examples of policy failure but not all result in a new policy paradigm, and the question as to whether something amounts to a policy failure is frequently a contested one. It could be argued that the ECS was an experiment that failed as a response to the rising policy concern with childcare costs, and that the FPSY represents the beginning of a radical shift in early childhood policy. The authors of this paper recognise the significance of the FPSY, and its potential to act as a lever to bring about more widespread change in future, but it has not yet overturned the features identified as defining the traditional policy paradigm.

\section{Conclusions}

The last 20 years of ECEC policy development in Ireland can be characterised as a period of rapid change without transformation. Describing the maintenance of a policy paradigm in which the Irish State has a limited role in direct service delivery, is reluctant to intervene in family matters and prioritises education over care, we suggest that a possible 
explanation lies in the power of ideas. A fuller explanation requires more detailed analysis of mechanisms of policy change and of the way policy ideas interact with different aspects of the policy-making process in Ireland, such as the political party system. Policy making in Ireland has been characterised as a combination of expedience and pragmatism, seen most strikingly in the ECS (Hayes and Bradley, 2009). It is not clear that these characteristics have gone away, so there remains a risk that policy development will continue to be ad hoc rather than strategic. Nevertheless, the Government's commitment to develop a National Early Years Strategy represents an opportunity to move towards a more strategic, long-term approach to policy-making, underpinned by a clear statement of national policy, which in itself would be a significant change from the situation described by Hayes (1995).

\section{References}

ADM (2000). National Childcare Census Report Baseline Data 1999-2000. Dublin, Area Development Management Ltd.

Adshead, M. (2008). State autonomy, state capacity and the patterning of politics in the Irish state. Contesting the State: Lessons from the Irish case. M. Adshead, P. Kirby and M. Millar. Manchester, Manchester University Press: 50-72.

Bunreacht na hEireann (1937). The Irish Constitution. Dublin, Stationery Office.

Centre for Early Childhood Development \& Education (2006). Siolta, The National Quality Framework for Early Childhood Education. Dublin, Centre for Early Childhood Development \& Education.

Clancy, M. (2006). Local radiotherapy for all in New Year. The Munster Express, Friday November 24th 2006.

Commission on the Status of Women (1972). Report of the Commission on the Status of Women. Dublin, Stationery Office.

Daly, M. (2010). "Shifts in Family Policy in the UK under New Labour.” Journal of European Social Policy 20: 433-443.

Daly, M. and S. Clavero (2002). Contemporary Family Policy - A Comparative Review of Ireland, France, Germany, Sweden and the UK. Dublin, Ireland, IPA for The Department of Social and Family Affairs.

Department of Children and Youth Affairs (2011). Comprehensive Review of Expenditure, Vote 43: Report of the Department of Children and Youth Affairs. 
Department of Children and Youth Affairs (2012). "Press Release: Minister Frances Fitzgerald Announces Preparation of Ireland's First National Early Years Strategy.” Retrieved 27/09/12, from http://www.dcya.gov.ie/viewdoc.asp?DocID=1751 Department of Education and Science (1999). Ready to Learn, White Paper on Early Childhood Education. Dublin, Department of Education and Science.

Department of Education and Skills (2010). A Workforce Development Plan for the Early Childhood Care and Education Sector in Ireland. Dublin: Department of Education and Skills.

Department of Finance (2000). "Financial Statement of the Minister for Finance, Mr. Charlie McCreevy T.D., 6 December 2000”. Retrieved 27/9/12 from http://budget.gov.ie/Budgets/2001/FinancialStatement.aspx Department of Finance (2009). "Financial Statement of the Minister for Finance, Mr. Brian Lenihan T.D., 7 April 2009”. Retrieved 18/04/13, from http://budget.gov.ie/budgets/2009Supp/FinancialStatement.aspx

Department of Social and Family Affairs. (2006, 03/04/06). "Press Release: Over One Million Children to Benefit From Child Benefit Increases \& 350,000 Also Qualify for New Childcare Support.” Retrieved 26/09/12, 2012, from http://www.welfare.ie/en/press/pressreleases/2006/Documents/pr030406.pdf.

Education Research Centre (1998) Early Start Preschool Programme: Final Evaluation Report. Dublin, ERC, Saint Patrick's College

Government of Ireland (1999). National Childcare Strategy Report of the Partnership 2000 Expert Working Group on Childcare. Dublin, Stationery Office Government of Ireland (2000). The National Children's Strategy Our Children - Their Lives. Dublin, Stationery Office.

Government of Ireland (2006). Child Care (Pre-School Services) (No 2) Regulations 2006 and Child Care (Pre-School Services) (No 2) (Amendment) Regulations 2006. Ireland.

Hall, P. A. (1993). "Policy Paradigms, Social Learning, and the State: The Case of Economic Policymaking in Britain.” Comparative Politics Vol. 25( No. 3 (Apr., 1993)): pp. 275296.

Hantrais, L. (2004). Responding to family change in Europe. Bristol, The Policy Press. Hayes, N. (1995). The case for a national policy on early education. Dublin, Combat Poverty Agency. 
Hayes, N. (2006) Perspectives on the Relationship between Education and Care in Early Childhood. Background Paper prepared for the National Council for Curriculum and Assessment (Dublin: NCCA).

Hayes, N. and S. Bradley (2009). Right by Children: Rights-Based Approaches to Policy Making in Early Childhood Education and Care. The Case of Ireland. DIT Centre for Social and Educational Research. Dublin, Dublin Institute of Technology.

Irish Childcare Policy Network. (2008). "Potential Impact of the Community Childcare Subvention Scheme \& Recommendations for its amendment and the development of a more fair and equitable funding system for childcare services." Retrieved 21/04/08, 2008, from http://www.nwci.ie/layout/set/print/content/view/full/423.

Jonsson, I., Sandell, A. and Tallberg-Broman, I. (2012). "Change or paradigm shift in the Swedish preschool?" Sociologia, Problemas e Practicas 69: 47-61.

Kaga, Y., Bennett J. and Moss P. (2010). Caring and Learning Together: A Cross-National Study on the Integration of Early Childhood Care and Education within Education. Paris, UNESCO.

Kuhn, T.S. (1962). The Structure of Scientific Revolutions. Chicago, University of Chicago Press.

Lloyd, E. (2012). Childcare Markets: an Introduction. Childcare Markets: Can they Deliver an Equitable Service. E. Lloyd and H. Penn, eds. Bristol, Policy Press.

Murphy, M. (2006). The emerging Irish workfare state and its implications for local development. Taming the Tiger: Social Exclusion in a Globalised Ireland. D. Jacobson, P. Kirby and D. O’Broin. Dublin, TASC at New Island.

National Association of Private Childcare Providers (2010). The Real Truth - Press Release, 20/3/2010, http://www.npcp.ie/. Ireland, Retrieved 24/08/2010.

National Council for Curriculum and Assessment (2009). Aistear, the Framework for Early Learning. Dublin, National Council for Curriculum and Assessment

National Women's Council of Ireland (2005). An Accessible Childcare Model. Dublin, National Women's Council of Ireland.

NESF (2005). NESF Report no. 31: Early Childhood Care and Education Dublin, National Economic and Social Forum.

O’Donoghue-Hynes, B. (2012). Designed to Benefit Whom? An evaluation of Irish Early Childhood Education and Care Policy using Policy Design Theory. Unpublished PhD thesis, Dublin Institute of Technology: 415. 
OECD (2004). OECD Thematic Review of Early Childhood Education and Care Policy in Ireland. Paris, Organisation for Economic Co-operation and Development.

OECD (2009). Doing Better for Children. Paris, Organisation for Economic Co-operation and Development.

OECD (2010). Gender Brief: Version: March 2010. O. S. P. Division. Paris, Organisation for Economic Co-operation and Development.

OECD (2012). Starting Strong III - A Quality Toolbox for Early Childhood Education and Care. Paris, Organisation for Economic Co-operation and Development.

OMCYA (2006). "Speech Material for Mr. Brian Lenihan, T.D., Minister for Children for Launch - Irish Presidency of the International Family Day Care Organisation.” Retrieved 2/6/11, 2011, from http://www.dcya.gov.ie/viewtxt.asp?DocID=259\&StartDate=1+January+2011. O’Sullivan, D. (2005). Cultural Politics and Irish Education since the 1950s: Policy Paradigms and Power. Dublin: Institute of Public Administration.

Pierson, P. (2000). “Increasing Returns, Path Dependence, and the Study of Politics.” American Political Science Review 94: 251-267.

PLANET (2008). The Impact of the Community Childcare Subvention Scheme on Children, Parents, Communities and Services. Dublin, PLANET Children's Policy Group.

Rush, M. (2006). "The politics of care" Care and Social Change in the Irish Welfare Economy. B. Fanning and M. Rush. Dublin, UCD Press: 46-64.

Scheiwe, K. and H. Willekens (2009). "Introduction: Path-dependencies and Change in Child-care and Preschool Institutions in Europe - Historical and Institutional Perspectives." Child Care and Preschool Developments in Europe Institutional

Perspectives. K. Scheiwe and H. Willekens. Basingstoke, Palgrave Macmillan: 1-22. Start Strong (2009). Pre-Budget Submission, November 2009. Dublin: Start Strong. Sweeney, J. (2007). Child poverty and child income supports. Welfare Policy and Poverty: 59. 